\title{
REVIEW OF REGULATORY DOCUMENTS AS REGARDS TAXATION ISSUES IN FEBRUARY-MARCH 2013
}

\author{
L.Anisimova
}

In the period under review, the most high-profile developments in the world economy were financial problems of Cyprus, visit of China's new leaders to the Russian Federation and the issues related to development of the principles of mutual relations with China in the sphere of economic cooperation. In the domestic economy, the issues of strengthening of the revenue base of regional and local budgets remained topical along with the issue of pseudo-taxes which kept emerging beyond the limits of the Tax Code of the Russian Federation, thus increasing compulsorily expenditures of goods manufacturers.

1. Cyprus is a country which joined both the European Union and the European Monetary Union and managed at the same time to transfer relations with Russia into a regime which was the most advantageous to it (not long ago Russia excluded Cyprus from the list of tax haven zones and concluded a double taxation treaty with Cyprus on standard terms which comply with standard procedures utilized in relations with countries with advanced market economies, that is, actually recognized low tax rates applied in Cyprus in respect of income received by Cyprian residents outside Cyprus as economically insignificant for development of effective market relations). Such an advantage has a logical explanation - Cyprus has become a EU member-state and Russia started to apply the same rules to it as to other EU member-states. As a result, Russian companies secured a strategically convenient financial settlements center directly in the territory of the European Union which permitted them to gain an easy access to the stock-exchange infrastructure. At the same time, the Russian business management center moved to the Cyprian offshore which situation ideally suited minimization of a tax burden on revenues ${ }^{1}$. To evade Russian taxation, Russian companies established in Cyprus their subsidiaries which became legal residents of that country. A change of the owner took place beyond the jurisdiction of the Russian Federation. Simultaneously, in Russia a Russian resident established a legal entity which a profitable business of the Russian company was assigned to and then the equities of that legal entity were bought for a large sum of money by the resident of the Cyprian offshore (Russian entities managed to secure in Russia exemption from taxation of income received from sale of equities of Russian companies, provided that the seller owned them for at least five years) and the Cyprian resident thus became an investor with a profitable subsidiary's business in Russia. Proceeds from sale of equities were also withdrawn from Russian on a legal basis - they bought a real property or established a trust. The above is not principally important for further analysis of the situation (it is just worth mentioning that the tax system of the Russian Federation helped some former compatriots become Europeans with preservation of the rent income received from Russia).

Financial offshore banks can exist and make money if settlement operations take place in their accounts all the time as a bank's revenues are a percentage difference between the attracted funds and deposited funds (in Cyprus the cost of bank assets exceed seven times over the country's GDP, so a constant turnover is vitally important to it). A partially financial business in Cyprus was based on circulation of funds in accordance with following scheme: a bank in Cyprus granted a Russian entity a loan out of funds placed by the Russian offshore company into deposits with that bank. The Russian offshore company (single-handedly or through an intermediary) would sell the produce of its subsidiary (in export of the produce VAT was not paid to the Russian budget)

\footnotetext{
1 The advantage of the Cyprian legislation consists in the fact that it complies with the English law. In carrying out transactions in Cyprus one receives protection of ownership rights within the frameworks of the English law, that is, beyond the Russian judicial system. The tax legislation for Cyprian residents is a favorable one: income from operations with securities and their derivatives (proceeds from sale of securities) is exempted from taxation (in Cyprus deemed as securities are shares, bonds and interests of company participants or other legal entities); the VAT rate amounts up to $15 \%$ (18\% in the Russian Federation), dividends tax, to 5\% (9\% in the Russian Federation) and profit tax, to 10\% (20\% in the Russian Federation).
} 
and repaid the loan on behalf of the borrower, thus replenishing its own deposit with the bank in Cyprus $^{1}$. But during the crisis due to falling demand on the produce financial turnover through Cyprian banks slowed down. Demand in loans against a commodity collateral decreased and, as a result, profitability of banking operations dropped a great deal.

In our view, in order to prevent capital flight from the banks and ensure stable payment of interests on the attracted funds Cyprian banks agreed on the EU scheme under which they bought the Greek bonds in return for the liquidity required both for carrying out current bank operations and financing government expenditures ${ }^{2}$. The main problems of the two largest private Cyprian banks "emerged after the Greek bonds were written off by 50\%"3. It seems that during the crisis other liquidity sources in the banking sector of Cyprus dried up. A condition for reciprocity between Cyprus and the European Union was probably a request that the former should cut the volume of its state expenditures: the European Union provided Cyprus with a fixed volume of liquidity and had no intensions to issue the euro in excess of the agreed upon volumes because stability of the euro ensured financial stability in Europe as a whole ${ }^{4}$.

By 2013, the need in expenditures for financing increased and exceeded the limits of the earlier approved volume of assistance (euro 10bn). Cyprus turned to the EU governing authorities with a request for euro 17bn worth of assistance, but failed to secure it. The Cyprian government's application to Russia for a new euro 5bn loan - in a situation where Cyprus's euro 2.5bn debt to Russia was still outstanding - was turned down, too. In the third decade of March, the EU approved a decision to grant Cyprus euro 10bn, provided that the Cyprian banking sector was restructured, a tax of over $30 \%$ on some types of deposits of over euro 100,000 introduced and other limitations on banking operations imposed after unblocking of accounts. It remains to be seen to what extent the crisis is going to be destructive for the banking sector of Cyprus. The country has preserved tax privileges that make it attractive to some types of transactions, but its banking sector has been safely integrated into the unified banking system of the European Union, that is, it will have to comply with the requirements of the regulator and be subject to tight supervision.

It appears that it was, to some extent, a pre-emptive strike aimed not at the Russian business, but at prevention of utilization of Cyprus as a base for a possible unchecked injection of inexpensive US dollars into the European banking system. It is to be reminded that not long before the financial crisis broke out large-scale buying of real estate in Cyprus was started by representatives from South-East Asia. The influx of the Russian capital sent once prices up in Europe, while the

1 According to Moody's, a rating agency, Russian banks which carry out operations with Cyprus-based companies of Russian origin and Cyprian banks put at risk $\$ 43 \mathrm{bn}$ to $\$ 53 \mathrm{bn}$ in total in case of the island's default. It is to be noted that the volume of Russian banks' funds deposited with banks in Cyprus was estimated by the above agency at $\$ 12$ bn, while that of Russian companies' deposits in Cyprus, at $\$ 19 \mathrm{bn}$. ("The Central Bank of the Russian Federation assures that the situation in Cyprus will not affect the Russian banking sector", Web-site of MK, March 19, 2013).

2 It originates from the comments of W. Schauble, German Finance Minister that Cyprus's two largest banks rely solely on the liquidity provided by the European Central Bank. "Somebody has to explain that to Cyprus", Mr. W. Schauble was quoted as saying by the Associated Press Agency (see Web-site of Kommersant.ru of March 20, 2013).

3 Interview of O. Viyugin, Chairman of the Board of Directors of the MDM Bank to the Ekho Moskvy Radio Station on March 27, 2013.

4 During the crisis, the structure of consumer demand undergoes changes due to the fact that capital is withdrawn from the business and hoarded. As a result, a part of the business becomes bankrupt and problems arise with realization of some products on the market - preference is given to the specific assortment of goods (basic goods, fuel and energy) - which situation is accompanied by growth in prices. Price-rises can be held in check only by way of limitation of solvent demand. As a result, people demand restoration of the former level of consumption, pay and pensions increase and other. It is obvious that in such a situation preservation of the EU agreed upon ultimate liquidity volumes provided to banks should be based on reduction of government expenditures and restructuring of the budget structure. The Cyprian government took another way in that situation: in 2011 it turned to Russia for help and was granted a state loan worth euro 2.5bn. The money was spent and an additional foreign debt was incurred. Non-monetary sources of repayment of that debt could be only taxes. Building up of state debts for repayment of the current state debt would just aggravate the risk of a necessary euro emission to the entire EU. Acquisition by Russia of property in return for the funds would, probably, have reduced automatically the quota of Cyprus in the European Union, but it would not have eventually solved that country's financial problems. In that situation, the decision of the Russian Federation to reject a new state loan to Cyprus was a well-balanced one. The proposal to convert (buy out) the Russian "frozen" deposits in Russian banks' interests in capital of Cyprian banks - as was suggested by M. Prokhorov (see: D. Nizhegorodtsev: "Mikhail Prokhorov Proposed a Salvation Plan for Cyprus", Web-site vz.ru, March 20, 2013) - was not endorsed by Russian banks as in the current situation it would be dangerous and inefficient to "freeze" the capital. 
unchecked inflow of inexpensive US dollars can produce a more serious destructive effect both on the European economy and the euro exchange rate - it was for that reason Latvia was sent a warning by the EU not to accept funds transferred from Cyprus.

2. An important event in the period under review was the election of the new leaders in China and their visit to the Russian Federation. Taking into account the fact that during that visit major agreements in different sectors of the economy were concluded, it is worth paying attention to some nuances which are important for development by Russia's leading companies of a strategy of further cooperation with China in order to achieve mutually beneficial relations.

It is believed that in development of relations with China one has to be guided by the same rules which countries with developed market economy follow. In particular, it is the EU legislation that is meant here; according to that legislation in the EU territory foreign state corporations must work on the same free market principles that were established for private companies. In accordance with the document on establishment of the European Union, absolute priority is attached to the interests of private companies and protection of the free and competitive market is declared as the goal of the state administration in the economic sphere. Russian leaders stick to the same position as regards the priority of the competitive market.

It is believed that no exceptions from the above rules should be made no matter how benevolent such relations may be. With seemingly convenient and easy contracting and large-scale volumes of deals which are typical of state corporations, one should not underestimate the fact that any state corporation is virtually a monopoly which (with a direct or covert support of its government) is seeking primarily to control prices and terms of entering into contracts on the foreign market. For a competitive market economy, access of "foreign" state corporations on such terms is unwelcome as it inevitably results in destruction of the private business in the territory of the country where that "foreign" corporation was granted access to.

It was shown in previous reviews that in production of identical products - unlike an ordinary competitive market participant - state corporations have explicit advantages which permit them to keep operating costs below the market level. As a state corporation has no need to insure commercial risks and is in a position to attract inexpensive borrowed funds (its obligations are deemed to be guaranteed by the government) it can afford to offer its produce at prices of the very low market segment. As a result, financial flows will get re-orientated at the products of a foreign "state corporation", while market entities of the country where that foreign state corporation was granted access to become unprofitable and lose their market. With absence of the competitive market, virtually all the financial resources are transmitted into a "foreign" economy in the form of payment for goods (jobs and services) of a "foreign" state corporation. Production capacities of domestic market participants get exhausted: their products fail to be sold, costs are left uncompensated, they have no funds to pay wages to their employees, so the latter quit in search of a better job. The competitive market eventually breaks down - it gets under complete control of a "foreign" monopoly.

Due to financial problems in Europe and reduction of sales in that market as a result of shale gas revolution, Russia is seeking to diversify its sales markets by expanding its presence on the Asian markets, particularly in China. China has amassed vast experience in doing business on the free market, so Russia has to cooperate with it on the basis of correct and mutually beneficial terms. It is to be remembered that primary products are real assets which are always in high demand on the market. The consumer cost of hydrocarbons as primary products is all the more high as they make up a material base of a very large range of products (in the form of primary products, fuel and energy) and exclusion of the above products from the international commodity exchange process by virtue of the existing structure of global production is highly unlikely in the near future though some market fluctuations may take place. At the same time, the market price of goods in terms of money value depends not only on consumer demand, but also purchasing power of currencies which are present on the market. So, fluctuations of the purchasing power of currencies should be taken into account in international commodity transactions related to deliveries of primary products. For a number of years, the USA has repeatedly drawn China's attention to the need of strengthening of the yuan. Lately, the USA has been actively carrying out the policy of quantitative softening of the US dollar in order to get out of the crisis. As China has to maintain the parity 
of the exchange rate between the yuan and the US dollar buying the latter for the yuan, it seems that some surplus funds have been created in China's domestic economy which funds it finds difficult to absorb so far and has to carry out sterilization by means of tax measures ${ }^{1}$. Raising of taxes is an inefficient decision as taxes forcibly limit business activities and may frighten off investors. Further US dollar softening may result in unfavorable growth in prices on China's domestic market. In such a situation, the most intelligent decision is, undoubtedly, reinvestment of surplus inexpensive US dollars into real assets. It would be an optimal decision for China: to fix prices on Russian primary products in US dollars for a long period of time and simultaneously weaken the US dollar pressure on domestic market prices. Though Russia crucially needs investments, it is to be remembered that hydrocarbons are a special commodity which forms the material base of the output of the present-day manufacturing, so it would be inadvisable to fix such prices for a long period of time in overbought currencies: if depreciation of currencies continues, hydrocarbons will appreciate as compared to contractual prices.

China's policy is aimed at long-term fixing of prices on supplies of primary products and fuel from Russia at prices which are lower than those at which Russia supplied (and keeps supplying) fuel to Europe. The above policy will ensure China competitive advantages in production within a long period of time. In entering into agreements, Russia has to avoid the following unfavorable factors:

1) slowdown of development of the domestic production in Russia (which is uncompetitive so far) which may increase due to growth in supplies of inexpensive goods from Asian markets; it is to be noted that a factor behind low prices on such goods will be the cost of primary products bought from Russia in future ${ }^{2}$;

2) subsidies may be charged from the Russian Federation on the markets of WTO-member states if the price on the domestic market happen to be lower than that on the European market.

3. In the period under review, the issue of expansion of the regions' tax base was keenly discussed in the mass media.

The property tax whose development was under way for almost 20 years is about to be introduced. S. Shatalov, First Deputy Minister of Finance of the Russian Federation informed the general public that "technical arrangements for introduction of a new individual property tax are virtually completed: Rosreestr has prepared cadastral registers of real property items being in ownership, including real property of individuals by all the constituent entities of the Russian Federation and large-scale evaluation of such property was carried out" ${ }^{3}$. Though verification of owners of real property has not been completed yet, the Deputy Minister of Finance believes that an actual transfer to the above tax can be started from 2014. Regions are in a position to take decision on introduction of the above tax until 2018. Until recently, the tax base of taxable real property items was calculated on the basis of the BTI inventory cost and happened to be 10-20 times lower than the market appraisal. As a result of the technical work done, instead of $30 \mathrm{~m}-35 \mathrm{~m}$ of taxable real property items the new registers now include $70 \mathrm{~m}$ real property items which the individual

1 The boom on the building market was temporarily suspended - China does not need expensive real estate which cannot be sold due to the fact that the domestic demand on it was not formed and the country is not interested in raising wages and salaries because inexpensive skilled workforce is an important competitive advantage of the Chinese economy.

2 For example, negotiations with China on gas supplies have been dragging for a few years due to the fact that both the sides cannot agree on the price of gas. Gasprom wants China to pay for Russian gas supplies the same price it receives from Europe, while China is seeking a discount. In particular, it was earlier said that if Europe buys Russian gas at $\$ 400$ per thousand cubic meters, China wants to buy it for $\$ 200$ (see: Both Oil and Gas. Major Agreements on Primary products Signed between Russia and China, Web-site Vz.ru of March 22, 2013).

The Metropol Group found a partner - NFC, a Chinese company - for development of Ozernoe, a zinc deposit in Buryatia. Investments in the project are estimated at up to $\$ 1.5 \mathrm{bn}$. If the project is implemented, the joint venture of Metropol and NFS with a capacity of 740,000 tons of zinc concentrate a year will become the largest Russian producer which surpasses UGMK (250,000 of zinc in 2012). However, analysts point out that in the past year and a half zinc prices did not appreciate due to the pressure on the part of China which became the largest zinc producer and manufacturer (A Dzhumailo: "They have found a Chinese Investor for Buryatsk zinc. Metropol has agreed with NFS on development of the Ozernoe deposit”, Kommersant daily No. 51 (5082) of March 26, 2013).

3 O. Samofalova. "It is not enough, anyway. Even a six-fold increase in revenues from the property tax will hardly make Russian local governments richer", Web-site of vz.ru of March 5, 2013. 
property tax is to be charged to. According to the Deputy Finance Minister, the maximum sum of those tax revenues which is expected to be received by local governments may amount to Rb 100bn to $\mathrm{Rb} 120 \mathrm{bn}$ as compared to $\mathrm{Rb} 20 \mathrm{bn}$ which is collected at present. The maximum tax rate will be set at the federal level and, allegedly, it is not to exceed $0.5 \%$.

Experts estimate cautiously the consequences of introduction of the new tax.

At present, local budgets receive local taxes revenues and allocations from federal and regional tax revenues. There are only two local taxes: the land tax and the individual property tax. In 2012 , with budget revenues of constituent entities of the Russian Federation amounting to Rb 8.0 trillion and the deficit, to $\mathrm{Rb} 0.4$ trillion, the share of regional and local taxes accounted for the one-tenth, including $\mathrm{Rb} 160 \mathrm{bn}$ worth of local tax revenues. From 2013, transfer of revenues from special tax regimes to the local level was envisaged. The share of revenues from special tax regimes in the revenues of the regions' consolidated budgets is equal to $4.5-7 \%^{1}$, so local governments will be handed over more than $\mathrm{Rb} 400 \mathrm{bn}$, but the aggregate deficit of the regions justified by introduction on the federal level ${ }^{2}$ of tax privileges as regards the profit tax and individual income tax will not eliminate the above reassignment of funds. With introduction of the property tax, the revenue base of municipal budgets may increase by another $75 \%$. According to experts' evaluations, a strong factor limiting further growth in revenues of that tax will be a low solvency level of a larger part of the population (the profit tax and individual income tax are paid in the form of a share of current incomes, while the property tax is charged on the basis of the cost of the property and its volume does not directly depend on the income of the payer, that is, the financial standing of the population).

Thus, as seen from the above the approved decisions on transfer of revenues of special tax regimes to the municipal level and introduction of the property tax will hardly solve completely the problem of absence of own funds in regions.

4. Mandatory payments introduced beyond the Tax Code of the Russian Federation and tariffs of natural monopolies are still a major problem for the economy. Here are a few examples to support that thesis.

4.1. It is explained by Resolution No. 5-P of March 5, 2013 of the Constitutional Court of the Russian Federation that in accordance with Article 16 of the Federal Law on Protection of the Environment a negative effect (pollution) on the environment is to be paid for. Attributed to negative effects are the following: air emissions of pollutants, discharge of pollutants and microorganisms in water and water catchment areas, pollution of soil, disposal of industrial and consumer waste, pollution of the environment by noise, heat, electromagnetic and ionizing emissions and other. Such a fee is not provided for by the Tax Code of the Russian Federation, as it is not a tax and the procedure for calculation and charging of it is set by the Government of the Russian Federation.

As was repeatedly stated in the reviews, if setting of a mandatory payment is delegated by the law to the Government of the Russian Federation the economic nature of such payments happen normally to be vague - it is unclear whether such a fee should be attributed to the methods of administrative pressure or paid services, nor are its limits (amounts) and collection procedure specified. Uncertainty around such issues often makes the Constitutional Court of the Russian Federation to solve later on the issues of application of such fees.

Resolution No. 632 of August 28, 1992 of the Government of the Russian Federation approved such a procedure for determination of the fee and its ultimate amount as is applied to legal entities and individuals which carry out any types of activities related to use of natural resources; also, the above procedure envisages charging of a fee for negative effects on the environment, including disposal of waste and sets general rules of calculation of such a fee. In accordance with a scheme of interrelations provided for by the Resolution, in disposal of waste arbitration courts established, in particular, that by accepting under an agreement the urban ore (UO) from other entities for

1 Calculations were carried out on the basis of the data of the Administration of the Altai Territory (Web-site: altairegion22.ru); The Federal Tax Service Department of the Kurgansk Region (published in the section: inspection/174214 on the Web-site: klerk.ru); B.Kh.Aliev. "Development of Special Tax Regimes in the Economy of the Region" as regards the Republic of Dagestan (published on the Web-site: uristmoscow.ru)

2 For reference: the share of the individual income tax amounts to about $53 \%$ of regional budget, while that of profit tax, property tax and other revenues, including revenues from special tax regimes, to over $16 \%$, about $23 \%$ and $8 \%$, respectively. 
burial at the landfill which is temporarily owned (leased) by the contractor entity the latter actually appropriated that UO (that is, the contractor entity was assigned the title to UO). As the fee is set on the basis of the level of the content of harmful substances (the level of pollution) in UO, the contractor entity which actually did not produce any harmful substances was recognized as the payer of a mandatory payment for a harmful effect on the environment. In addition to the above, as a small enterprise which carries out disposal of waste at the leased land plot did not develop a document - which was to be executed in accordance with the adopted procedure - on approval of both the norms of formation of the waste and the limits on disposal of such a waste, the specified fee for a negative effect on the environment is to be calculated with taking into account a five-fold multiplying factor.

OOO Topol, a small business enterprise disputed the above procedure at the Constitutional Court of the Russian Federation; it believed that the payment set by the abovementioned statutory acts did not comply with the Constitution of the Russian Federation. In particular, it was stated in a lawsuit that as the law did not specify liable persons (those who are obligated to make a payment) the payers of mandatory payments were designated by courts of arbitration. In addition to the above, as UO is created as a result of activities of other persons, contractors should not be obligated to make payments for the negative effect produced by those persons on the environment. The applicable legislation (the environment payment has the status of a mandatory payment) does not permit to include in tariffs on waste collection services (transportation and disposal) the amounts paid by contractors for exceeding of the norms by "the sellers" of the waste (according to the stance of the Supreme Commercial Court of the Russian Federation). The plaintiff pointed out that liquidation of landfills would result in violation of the Constitution as numerous unauthorized dumps emerged and people's constitutional right to satisfactory and healthy environment was infringed.

Having taken up the case, the Constitutional Court of the Russian Federation came to the conclusion that it was not so much the fiscal interest of the government to replenish the coffers as the common interest to preserve the environment and ensure environmental security that constituted the legal basis of ecological payments. Those payments were mandatory legal payments for the government's measures aimed at protection and recovery of the environment from the consequences of business and other activities which had a negative effect on the environment within the limits of the norms (set by the government) of such an admissible effect; those payments were of individual indemnification and compensating nature and according to their legal nature they were not a tax, but a fiscal fee. The Constitutional Court of the Russian Federation confirmed its position which was set out earlier in Ruling No.284-O of December 10, 2002 to the effect that payment for a negative effect on the environment was a form of indemnification of the economic damage from such an effect and it is charged from those business entities whose activities were actually related to the negative effect on the environment. The Constitutional Court of the Russian Federation came to a conclusion that legislators should eliminate loopholes in the legislation on protection of the environment and bring statutory acts in harmony with the Constitution of the Russian Federation.

Unfortunately, the economic meaning of the notion "legal payment" which is of an indemnifying and compensating nature is not quite clear. Let us explain that. As was shown above, the person who was allocated a duty to pay at its own account for restoring the environment to the original state may not necessarily be in a position to meet that requirement for financial reasons. One cannot but agree with the Constitutional Court of the Russian Federation that restoration of the environment is a government function. The above payment is sooner a fee (in the amount of complete or partial cost of the required work) which the government may collect for its services related to restoration and preservation of a favorable ecological situation. If the above service is carried out by somebody else and not by the government, such a payment in the volume of the service provided should be transferred to the person who actually fulfils that service. However, the "legal payment" formula set by the law as a mandatory payment with preset parameters does not permit to do that.

As it can be seen, introduction of mandatory payments in the legislation beyond the Tax Code of the Russian Federation actually results in compulsory growth in manufacturers' costs: though by its economic nature, the payment in question should be transferred to the government (that is, in the budget) less expenditures related to payment for the third persons' waste disposal services, it 
seems it will be allocated in the full amount (with a fivefold multiplying factor applied) to the aftertax profit (as a sanction for exceeding of the norms of utilization of natural resources).

4.2. The procedure for setting of tariffs on goods (jobs and services) of natural monopolies is by no means an easier problem for public justice. It is also a payment aimed at indemnification of expenditures related to provision of public services. In a conflict discussed below, the plaintiff appeals to the fact of absence of competitive conditions for formation of prices. According to the plaintiff, by virtue of that it incurs economically unjustified mandatory expenditures which reduce artificially its profitability.

In a lawsuit - filed by OOO AkvaReil - on recognition as null and void of provisions of Order No. 78-t/1 of May 4, 2012 of the Federal Service on Tariffs (FST) of Russia on Introduction of Amendments and Additions to Price List No.10-01 "Tariffs on Cargo Carriage and Infrastructure Services by Russian Railways", it is stated that by the above Order tariffs discriminating the terms of access to OAO RZhD services were introduced. In particular, for light running of a grain carrier hopper wagon a fee is charged which largely exceeds the fee for light running of a low-sided car or flat wagon which situation puts the person which provides consumers with hopper wagons for transportation of grain in a position which is not equal to that of other business entities which provide low-sided cars for carriage of alumina and other cargo. The plaintiff believes that for the purpose of non-infringement of the norms of protection of competition determination of payments for light running of grain carrier wagons should be carried out on the basis of the same rules which determine the fee for light running of low-sided cars.

The issues of determination of tariffs on railway transportation were repeatedly considered by the Supreme Commercial Court of the Russian Federation (SCC RF).

In its decision No.VAS-17239/12 of March 7, 2013, the Supreme Commercial Court of the Russian Federation drew the plaintiff's attention to the fact that the government of the Russian Federation approved the Plan of Structural Reform Measures on the Railway Transport. By means of the above Plan, the Government of the Russian Federation determined the creation of a special-purpose model of cargo railway carriage till the year 2015, which model had to envisage unification of tariffs on light running of the own (leased) freight wagons irrespective of the class of the earlier transported cargo with taking into account reduction of the size of cross-subsidy in tariffs on transportation of cargo of different tariff classes. It is to be noted that the program of structural reform of the railway transport and the special-purpose model of the market are also an integral part of implementation of the Transport Strategy of the Russian Federation till 2030 and the Strategy of Development of the Railway Transport in the Russian Federation till 2030 approved by the Government of the Russian Federation (within the frameworks of Instructions No. 1734-r of November 22, 2008 and Instructions No. 877-r of June 17, 2008).

The reform in question is meant to gradually divide the market into the owners of the railway transport infrastructure (the infrastructure includes railway lines, electrical facilities, communications, stations and other) and carriers (owners of rolling-stock and a fleet of locomotives). Before such a division is accomplished it is hardly possible to achieve equality in terms of operation of wagons as the plaintiff wants. The thing is that OAO RZHD is still the owner of not only the railway infrastructure, but also a large fleet of wagons and locomotives. As the fleet of wagons owned by OAO RZHD wears down, they expect to write them off and replace with private fleets of cars. At the next stage, it is planned to replace the fleet of locomotives of OAO RZHD for private ones. In such a situation, before the reforms are completed differentiation of tariffs is inevitable as the fleet of wagons of OAO RZHD needs to be gradually liquidated and tariffs paid by the fleet of wagons to be liquidated and those paid by fleets of private wagons do not enter into market competition with each other: a private company is charged a fee for utilization of the infrastructure -which fee is a market price - while empty mileage of RZhD cars is RZhD's own expenses.

At present, the actual problem consists in the fact that during the crisis restructuring of the railway transport has slowed down. The danger of such a slowdown was repeatedly stated in the mass-media by the management of the railway transport. Carriers have raised for a long of time 
the issue of making railway carriage accessible to private fleets of locomotives, but it seems that during the crisis for OAO RZhD the utilization of its own fleet of wagons and locomotives remains the most reliable source of financing of expenditures related to maintenance and overhaul of the railway infrastructure.

The plaintiff is undoubtedly right in its approach, but its lawsuit is, unfortunately, premature. However, the above lawsuit reflects a principally different trend in development of the Russian business - the manufacturer of goods wants to know for what reasons the schedule of restructuring of OAO RZhD was upset due to which factor the manufacturer's business incurred losses and further business development was complicated. The Government of the Russian Federation should seriously handle those issues and develop the mechanism that prevents disruptions of the work schedule - because the above factor is a serious problem which makes the investment climate unfavorable in the Russian Federation.

4.3. Another problem consists in assignment of the right to determine the tariffs to the monopoly. The following example deals with prices on housing and public utilities services. In 2012 , the annual growth in tariffs in some regions amounted to over $200 \%$ and reasons for such high growth were not justified enough. The danger of a monopoly consists in the fact that it first minimizes the price to ruin its competitors and then it includes a pseudo-tax in the price for its services in order to compensate the losses incurred. The most dangerous situation takes place when regional leaders are approached by persons who participate in the monopoly's income.

Such a situation cannot but become socially explosive.

Taking into account the fact that in the past few years tariffs on housing and public utilities services grew at the rates which exceeded twice as much the inflation rate and the quality of those services did not improve, a decision was taken to consider that situation at the meeting with the President of the Russian Federation. On the basis of the results of that meeting, a decision was taken on the ultimate increase of $6 \%$ in the tariffs in 2013; Instructions No. DK-P9-1327 of March 1, 2013 of the Government of the Russian Federation was prepared (it was signed by D. Kozak, Deputy Chairman of the Government of the Russian Federation). The outputs of fulfillment of the above Instructions were the guidelines developed by the Federal Tariff Service of Russia and dispatched by Letter No.SN-2164/5 of March 6, 2013 to executive authorities of constituent entities of the Russian Federation.

According to the above guidelines, a $6 \%$ growth in prices for public utilities services on the annual average basis with taking into account the fact that in the first half of 2013 prices were not increased means that in the second half of 2013 the maximum growth will amount to $12 \%$ (in municipal entities with domination of the aggregate payment of households for power and gas supply services growth in tariffs will not exceed $15 \%$, while at garrisons the amount of the tariffs is determined by agreement with the Federal Tariff Service of Russia).

Among technical issues, it is worth mentioning the following:

5. Letter No. ED-4-3/4184@ of March 14, 2013 of the Federal Tariff Service of Russia explains application of reduced VAT rates in taking of goods manufactured in the territory of other memberstates of the Customs Union (CU) to the Russian Federation. In accordance with Article 2 (5) of the Protocol of December 11, 2009 on the Procedure for Charging Indirect Taxes and the Mechanism of Supervision over Payment of Such Taxes in Export and Import of Goods to the Customs Union, the amount of indirect taxes liable to payment for goods imported to the territory of one memberstate of the CU from the territory of another member-state of the CU is calculated by the taxpayer on the basis of tax rates set by the legislation of that member-state of the CU which territory the goods are imported to.

In import of goods to the territory of the Russian Federation, the VAT should be paid at rates set by the Tax Code of the Russian Federation. Reduced rates are applied if the name and the Customs Union Commodity Classification of Foreign Economic Activities code of imported goods comply in full with sub-positions provided for those goods in the Russian Federation (for example, as regards baby goods charged at a reduced VAT rate of $10 \%$ only juice in the package of $0.3 \mathrm{~L}$ is acceptable). In other cases, the general VAT rate of $18 \%$ is applied. 
6. Weakening of the institute of banking secrecy under the pressure of requirements of tax authorities is becoming more evident in the Russian Federation. Letter No.31-T of February 27, 2013 of the Central Bank of the Russian Federation and Letter No. AS-4-2/22679 of December 29, 2012 of the Federal Tax Service of the Russian Federation set out new requirements to disclosure of the information on bank accounts to tax authorities due to approval of Federal Law No.97-FZ of June 29, 2012 on Amendment of Part 1 and Part 2 of the Tax Code of the Russian Federation and Article 26 of Federal Law on Banks and Banking.

From January 1, 2013, banks (in addition to the information on accounts and electronic cash funds) have to provide tax authorities with information on deposits with banks and (or) balances in deposits, as well as deposit statements. The information is to be provided as per request: 1) certificates on accounts (special bank accounts); 2) certificates on account balances (balances on special bank accounts); 3) account statements (special bank account statements).

7. By Federal Law No. 29-FZ of March 14, 2013 on Amendment of Individual Statutory Acts of the Russian Federation, branches of foreign banks have been excluded from the banking system of the Russian Federation. Subsidiaries of foreign banks - independent legal entities under the Russian legislation - are allowed to carry out activities. The main factor behind that decision was the fact that a Russian bank is issued a Russian license, it is subordinate and accountable to the Central Bank of the Russian Federation and has a balance-sheet of its own. The Russian banking legislation is not applied in full to foreign banks' branches, their accounts show only those operations which they carry out, so the ratios and norms set by the Central Bank of the Russian Federation are not mandatory for them. 